\title{
IS IT POSSIBLE TO ANALYZE PETROGLYPH MOVING FROM IDIOMS? THE MEANING OF TAIL TYPES IN TAMGA SHAPED MOUNTAIN GOAT FIGURES ${ }^{1}$
}

\author{
İbrahim Şahin ${ }^{1}$ \\ 1)Ege Üniversitesi, Türk Dünyası Araştırmaları Enstitüsü, Türk Dili ve Lehçeleri ABD, \\ ileti: miharbisahin@hotmail.com, ORCID ID: 0000-0002-0167-2568
}

\begin{abstract}
Petroglyphs are important language of communication of history without illustrators and readers. In this article, the possibility of analyzing petroglyph based on idioms emphasizes and a research method model is presented. Tail types encountered in tamgha shaped mountain goat figures were investigated by using "The Method of Petroglyph Analysis based on Idioms". The results of analysis on selected idioms from three dialect groups of Turkish language showed that 'tail' refers 'honor' and 'power'. Accordingly, the long and upright tailed mountain goat tamgha is the symbol of honor and power of khan. Another conclusion is the limiting rule in drawing these figures. Accordingly, the tamghas drawn must correspond to the social status of the person it represents. So the long upright tail could be drawn to represent the khan and the dynasty. All of these conclusions points out the importance of petroglyphs, as a visual material, in the social communication process.
\end{abstract} cultures

Keywords: Petroglyph, Mountain goat figure, Tail, Idioms, Communication, The language of historical

\section{DEYIMLERDEN HAREKETLE PETROGLİFLER ÇÖZÜMLENEBİLİR Mİ?: TEKE PETROGLİFLERİNDE KUYRUK TİPLERİ VE ANLAMLARI ÜZERİNE}

\section{Özet}

Petroglifler, günümüzde geleneksel usulde çizeri ve okuyucusu olmayan ölü bir kültürdür. Artık kayalara petroglif çizen kimse kalmadığı gibi kayalara asırlar önce çizilmiş petroglifleri geleneksel şekilde anlamlandıran birileri de kalmamıştır. $\mathrm{Bu}$ durumun modern petroglif araştırmacılarının önünü tıkadığı bir gerçektir. Petroglifleri anlamlandırmaya çalışan araştırmacıların çoğu kez betimsel bir yaklaşımla, resimlerdeki görselleri görmeyen birisine anlatır gibi anlattıkları görülmektedir. Bu makalede, petrogliflerin anlam çözümlenmesinde yaşanan yöntem sorununa çare aranmış; bir başka ezelî kültür olan deyimlerden hareketle petrogliflerin çözümlenebileceği üzerine durulmuş ve buradan hareketle bir yöntem modeli sunulmuştur. Sunulan bu yöntemle, Türklerin tarihî yurtlarında görülen teke figürlü tamgalarda karşımıza çıkan kuyruk tipleri, özellikle kağan yazıtlarında uzun ve dik kuyruğun anlamı üzerinde durulmuştur. Bu yapılırken Türk dilini temsil eden üç farklı lehçe grubundan üç ayrı lehçe seçilmiş ve bu lehçelere ait deyimlerde geçen "kuyruk" sözcügünün sembolik anlamı analiz edilmiştir. Bu inceleme sonucunda, her üç lehçenin deyimlerinde, dolayısıyla Türkçenin uzak derinliklerinde, "kuyruk" sözcügünün birbiriyle ilişkili olan 'şeref, haysiyet' ve 'güç, erk, kudret' kavramını ifade ettiği sonucuna ulaşıışstır. Bu sonuç, Orhun Yazıtları'nda, kağan tamgalarında abartılı bir biçimde karşımıza çıkan uzun ve dik kuyruklu teke tamgasıyla birlikte düşünülmüş ve gelinen noktada söz konusu tamganın, temsil ettiği kağan ve kağan sülalesinin yüksek şeref ve kudretini sembolize ettiğine hükmedilmiştir. İncelemenin ortaya çıkardığı sonuçlardan biri de, teke figürlü tamgaların çiziminde, o devirde toplumsal bir kuralın varlığına işaret ettiği yönündedir. Buna göre çizilen temga, temsil ettiği kişinin toplum içindeki statüsüne uygun olmak zorundadır. Bu çerçevede uzun ve dik kuyruk, o devirde ancak kağan ve hanedanı temsil için çizilebilirdi.

Anahtar Kelimeler: Petroglif, Dağ keçisi figürü, Kuyruk, Deyimler, İletişim, Tarihsel kültürlerin dili

\footnotetext{
1 This article is the revised and the same named version of the proceeding presented and published in XIIth International Grand Turkish Language Congress (pp. 90-95) booklet that was held in Bucharest on 25-28 September 2017.
} 


\section{Introduction}

In the past, some cultures that encapsulate all members of the society and has been used as a tool of communication between them, may lose their vitality over time; even they can be forgotten completely. Prehistoric culture known as "rock art" is one of them. If the rocks on which the figures were drawn had not reached these days by defying time, there would be no trace of this enormous archaic culture. As today, there is neither a person drawing a picture on the rock in a traditional way, nor a person who can express his/her emotions and thoughts by this way and read the messages in them.

In many parts of the world, these rock arts, which are usually depicted on rocks in hilly high mountainous areas, sometimes in caves and sometimes on exposed rocks, attract the attention of scientists such as anthropologists, archaeologists, ethnologists and philologists, and the studies carried out so far forms a large literature. Generally, it is seen that these studies concentrate on a. Determination of rock arts; $b$. Recording them; c. Dating or how they may be dated; d. Style difference or similarity between the rock arts found in different geographies.

Rock arts contain information about the life, occupation and beliefs of the people drawing them at the time. Therefore (petroglyphs) are among the indispensable objects of rock arts. The animal figures (petroglyphs) depicted sometimes in hunting, entertainment and sometimes in a natural landscape, etc. can be the subject of drawing sometimes in a herd and sometimes alone. One of the most common objects of the drawings, perhaps the first is the mountain goat petroglyph in the regions where densely populated by Turkic speaking peoples such as Asia minor (Alok 1998; Mert 2007: 233-254; Şahin 2012: 275-300; Somuncuoğlu 2012); Caucasus (Caferzade 1999; Alyllmaz 2016); Central Asia (Samashev 2001: 151-220; Tashbayeva 2001: 9-79; Khujanazarov 2001: 80-121); Southern Siberia (Kubaryev and Matochkin 1992; Martinov 2013); Mongolia (Okladnikov 1981; Novgorodovas 1984). They appear everywhere alone or in a group. Researchers state that the mountain goat petroglyphs determined in these geographies are similar in style (Grach 1973: 316-333; Marikovskiy 1999; Demir 2010: 5-23; Somuncuoğlu 2012). Although, the definitions such as "Angara Style", Minusinsk style", "Pazyryk style" used for petroglyphs in these regions are appropriate, there are the researchers who emphasize the necessity of using more chronological and regional style definitions for Central Asia and for recent Turkic, Middle Ages periods (Francfort 2001: 7); which in our opinion, is an appropriate assessment.

Although a certain maturity has been reached in the discovery, compilation and album works of the rock arts in these regions, which are mostly carried out by archaeologists and historians during a period of nearly a hundred years, it is seen that there is no progress in decoding the language of petroglyphs, its role in the process of social communication and the messages they contain. As it is no longer a living culture, it is not possible to obtain information from the public through face to face interviews. The fact that the historical sources are silent on this subject obstructs the way to reach a healthy result with the historical method. In descriptive researches, the rock arts are evaluated in terms of drawn objects, drawing techniques, etc. and they tell about these drawings as if they tell to someone blind. Looking at the subject from the perspectives of the fields other than archeology and historiography can produce results. As a matter of fact, this study is the result of such an effort.

\section{Objective-Method}

In this study, a method model for the analysis of the meaning of petroglyphs will be presented. This method, which we can be called as "The method of petroglyph analysis based on idioms" is based on the idea that the elements of the drawings can be explained based on idioms. According to us, on one hand while the people in those ages turned their emotions, thoughts and understandings into verbal culture through idioms, on the other hand, they expressed the same feelings, thoughts and understandings with the drawings on the rocks. For example, as discussed in this study, the mountain goat figure has been the subject of rock arts everywhere and if its tail is exaggeratedly upright and long in some drawings, it means that it is used as an ideogram and that there is a message, understanding, thought intended to be communicated to people with it.

However, that this (drawing on rocks) is a dead culture makes it impossible for us to learn the message they contain. Because there is no illustrator and reader traditionally, it is not possible to obtain information by compilation technique from the people who draws them on the rock or the people who read the messages.

However, the spoken language is continuous. In particular, stereotype expressions such as idioms and proverbs are ethnographic language materials carrying the understanding of a nation since early ages. It is 
possible to deduce the symbolic meanings of the concepts subject to idioms. As a matter of fact, in this study, the symbolic meaning of the concept of 'tail' in the idioms can be clearly determined and from this information it could be possible to explain the meaning of the long upright tailed mountain goat figure drawn at the top of Old Turkic inscriptions. This result indicates that the method in question (The method of petroglyph analysis based on idioms) can be used to explain many similar subjects depicted in rock arts.

It is of course not possible to examine all the elements which are the subject of rock arts, each element in petroglyphs and their details in a single study. For this reason, the tail types of the mountain goat petroglyphs, which are used as a remarkable element in the mountain goat petroglyphs which are frequently encountered in the historical motherland of the Turks (Central Asia, South Siberia), will be examined and the meaning of the exaggerated upright and long tail in some petroglyphs will be investigated. For this purpose, three dialects were selected from the three major branches of the Turkic language (one in each). Turkey Turkish and its idioms were chosen to represent the Oguz Group (consisting of dialects spoken in Turkey, Azerbaijan, Turkmenistan, Gagauz, Iran, Iraq, Cyprus, Greece and Bulgaria) and Kyrgyz Dialect and the idioms of this language were chosen to represent the Kipchak Group (the group of Turkish dialects spoken by Tatars, Bashkirs, Kumyks, Kazakhs, Kyrgyz, etc.). Uighur Dialect was chosen to represent the Karluk Group (the group of Turkish dialects spoken by the Uighurs and Uzbeks). In this way, it is envisaged to reach the common points overlapping in the idioms of three dialects, in other words, the most historical and essential meaning of the idioms. With this prediction, first, the idioms made with the word 'tail' in the said dialects (Turkish, Kyrgyz, Uighur) were determined. Then, the symbolic meanings expressed by the word 'tail' in these idioms were determined. In the last stage, the meaning overlapping in three dialects, that is, the common point, were determined. Tail types in mountain goat petroglyphs were explained by considering that this common meaning is the most historical and essential meaning for the Common Turkish language.

In 1889, the famous researcher N. M. Yadrintsev discovered Old Turkic and Chinese engraved inscriptions on the Koço Saydam region of Mongolia and this discovery had aroused great excitement in the science circles. It was soon determined that the inscriptions deciphered by $\mathrm{V}$. Thomsen belong to II. Turk Khaganate and were written in the first half of the eighth century. Along with the inscriptions made in honor of the rulers of the state, petroglyphs with mountain goat figures were also found at the top of the inscriptions. V.Radlov, accepted as the founder of Turcology, asserted that the mountain goat petroglyphs engraved with the inscriptions of Ongin (dating back to 720), Ashete (724), Kultegin (732), Bilge Kagan (735) and engraved at the top of the inscription on many tombstones are "xanskaya tamga" ('khan tamga') and it is the symbol of dynasty of Turk Khaganate state (Radlov 1892: 16-17).

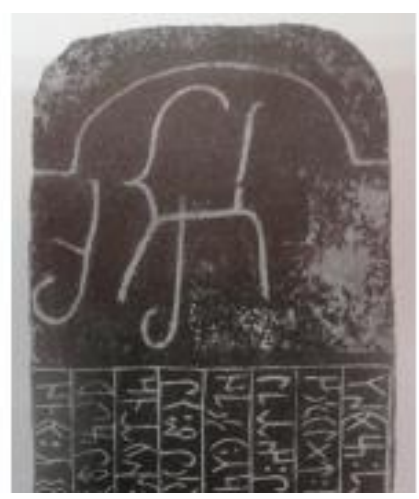

Mountain goat figure in

Ongin inscription (Radlov 1892: 63)

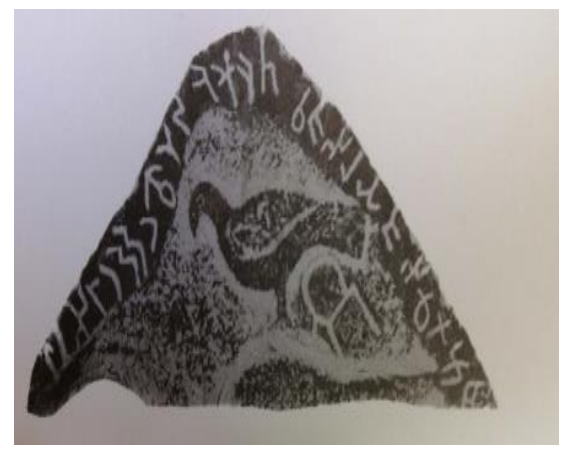

Mountain goat figure (under the bird figure) in Ashete inscription (Radlov 1892: 64)

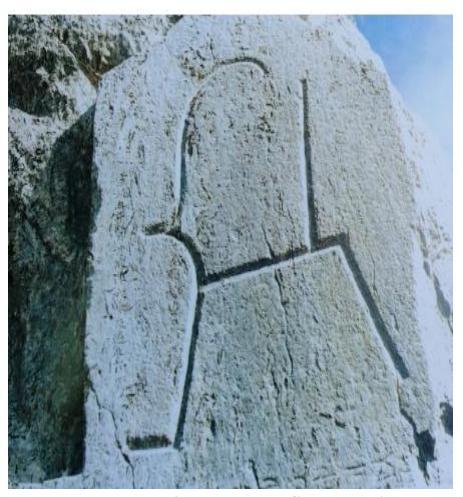

Mountain goat figure in

Kultegin inscription

(Aly1lmaz 2005: 14)
In addition to the above mentioned inscriptions, that there are the same mountain goat tamghas in Tuva on the tombstones from the same state, and that the same tamghas are seen among the rock arts in the regions extending from Mongolia in the 
east to Tamir and to the Pamir-Alay regions in the west attracted great attention of Russian scientists. Researches were made to determine the dating and concepts. First in 1925, G. İ. Borovka determined that the mountain goat tamghas at top of the inscriptions and the mountain goat figures on the rock arts are the same (Grach 1973: 317). In the light of the discoveries such as the mountain goat figure (depicted with knees bent and in leaping position) excavated by A. N. Benştam in Pamir and dating back to fourth-fifth century BC and the mountain goat figures (depicted as being chased by dogs) excavated by L. R. Kyzlasov in Kyrgyzstan and dating back to fifth-tenth centuries BC and similar discoveries, A. D. Grach determined the properties of the goat figures of the period (VI-VIII. century) by comparing the goat tamghas found in different periods, geographies and remaining from ancient Turks and the goat figures on the rocks (see table below). According to him, that the body details of the mountain goats (body, feet, face, horn) are drawn in the same thickness, that demonstration of mountain goat figures from the profile, the depictions of animals standing or jumping are the analogies among the figures (Grach 1973: 318-320). The researcher stated that these figures were found in almost every place where the Old Turkic tribes settled (Mongolia, Tuva, Kazakhstan, East Turkestan, Fergana) and stated that these studies can be used as a source for the investigation of the ethno genetic process and historical cultural relations of petroglyphs (Grach 1973: 323).
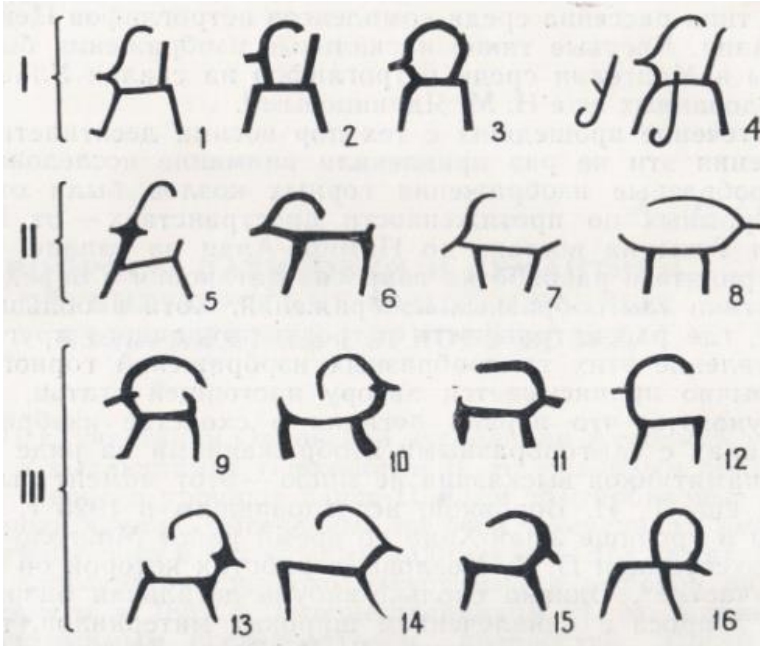

12
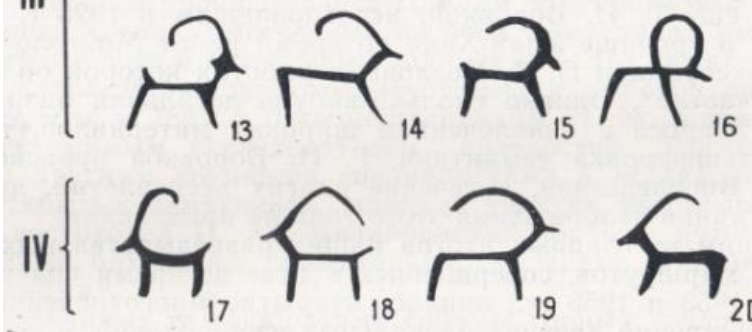

Geographical comparative table prepared by A goats belonging to Old Turkic period (Grach 1973: 318).

A. D. Grach interprets the meaning of the mountain goat figure based on the relationships (from information on the inscriptions) between Bilge Kagan and Kultegin. He further states that the inscription of Kultegin was made just like the khan inscription and a mountain goat figure was placed at the top as Bilge Kagan owed his own power to his brother Kultegin and mountain goat tamgha is "the symbol of sovereignty and khanate" and his opinion is supported by the researchers such as Ranov, Maksimova, Dorj, Vaynşteyn, Saviov, Formozov, Batmanov, Aragaçi, Klyaştorniy, Lariçev, Bernştam, Gryaznov, Şer, Çernikov, etc. (Grach 1973: 322).
I Khan's tamgas (Mongolia);

II: Mongolian petroglyphs;

III: Petroglyphs in Tuva;

VI: Petroglyphs in Kazakhstan

1. The monument of Kultegin, (Orhun);

2. Stone sculpture, Orhon (from Radlov);

3. Tablet in Ashet (from Radlov);

4. The tombstone with inscription, Ongin (from Radlov);

5. Ulan Hada (from Borovka);

6. Tebçi (from Larichev);

7-8. Tsagan-Gol (from Grane);

9. Çuruktug-Kırlan;

10. Ovyur IX;

11. Çuruktug-Kırlan;

12. Tombstone, Bulun;

13. Ovyur V;

14. Ovyur XII;

15. Teve-Haya;

16. Çuruk-Maldıg-Haya Haya (from Grach);

17-20. Culak Mountains (from Marikovskiy)

. D. Grach for the depictions of tamgha shaped mountain 
independence and freedom, determination, agility, speed, summer, abundance, movement, wealth, nobility, courage and sovereignty" (Alylmaz 2016: 351). Considering the matter within the framework of beliefs and legends about the mountain goat among the Turks living in Anatolia, N. Demir stated that it would not be possible for it to symbolize "productivity, courage and determination" due to the character of the mountain goat; however, he confessed that he could not find an answer to the question of why the mountain goat figure was so widespread (Demir 2010: 22).

As it can be seen in above mentioned comparative table of the mountain goat figures prepared by Grach, the mountain goat figures at the top of khan inscriptions from Turk Khaganate in the middle of eighth century and the mountain goat figures seen on the petroglyphs on the rocks have great similarity. However, it is remarkable that the tail of the mountain goat figures in the khan inscriptions is quite long and upright.

The presence of long upright tailed figures in the khan inscriptions undoubtedly indicates that these figures were used as ideograms. The ideology or cultural meaning of the long upright tail, which is understood to be particularly emphasized in the ideogram, has been examined by the method detailed above. The idioms of the selected Turkic dialects and meanings are as follows:

\section{Turkey Turkish}

The "kuyruk" ('tail') in the idioms of

The idioms of Turkey Turkish mainly compiled from the dictionaries; Örnekleriyle Deyimler Sözlïğ̈ (Yurtbaşı 1996) and Atasözleri ve Deyimler II (Parlatır 2008).

1. "Ölür gider kuyruğu dik gider" ('He died but the tail is upright'): Not to ask favor from anyone. It is used to describe people who never compromise their honor and do not give up their behavior even if they fall into difficult situations.

2. "Kuyruğunu kıstırıp kaçmak" / "kuyruğunu bacaklarının arasına kısmak" / "kuyruğunu kısmak" ('To pinch the tail and run away' / 'to put the tail between the legs' / 'to lower the tail'): Speaking with low voice and hiding because of fear.

3. "Kuyruğu dik tutmak" ("Holding the tail upright'): Trying not to show that he is in bad manner and to give the impression that he is strong.
4. "Kuyruk sallamak" ('Wag the tail'): Flattering, flirting. The idiom is used to describe people who flatter or compromise their robust, strong, honorable stance.

5. "Kuyruğuna basmak" ('Stepping on someone's tail'): To hurt a person financially and morally, to touch his interests, personality.

6. "Kuyruğunu kesmek" ('Cutting someone's tail'): To ruin, deplete someone's strength, force, to destroy.

7. "Kuyruk acis1 olmak" ("Having a pain in the tail'): To be in a sense of revenge, to have a grudge against.

8. "Kuyruğunu kaptırmak" / "kuyruğu ele vermek" ('To give the tail to someone's hands'): Falling into someone's hands.

9. "Kuyruğu kapana sıkışmak" ('To stuck the tail in trap'): To fall in a bad situation difficult to get out, to fall in a bad situation. It is used to describe people whose power and honor is in danger.

10. "Kuyruğu, kuskunu dökülmüş" ('His tail, crupper is run down'): To lose the reputation and discredited.

11. "Kuyruğu düşmek" ('His tail fell down'): Being about to die. It is used to describe people who have lost their power.

12. "Kuyruğu titretmek" / "kuyruğu dikmek" ('Shaking the tail' / 'Erecting the tail'): To die.

13. "Kuyruğu omuzlamak" ('Shoulder the tail'): To run away, to walk away.

14. "Kuyruğuna teneke bağlamak" ('To attach a can to the tail'): Extremely ridiculing with a person, humiliating a person.

15. "Kuyruksuz aslan olmak" ("Being a tailless lion'): To act as strong although really powerless.

16. "Kuyruğu yere bakmak" ("His tail is looking down'): Being about to die. It is used to describe the condition of a person who is sick or near-death by losing healthy appearance.

17. "Kuyruğu dikmek" ("Making the tail upright'): To improve financial status, to get rid of disease, 2. That a cow starts to run by making its tail upright. 
18. "Kuyruğunu kaldırmak" ('Lifting someone's tail'): To help someone, to provide that his works get better (making a person strong and powerful).

19. "Kuyruğu uzun olmak" ("Having along tail'): Being a person whose work never ends.

20. "Kuyruk olmak" ('Being a tail'): To tag behind someone, to be an add-on.

21. "Kuyruğa girmek" / "kuyruk yapmak" / "kuyruk olmak" ("To join the tail'). Join the queue for something.

22. "Kuyruklu yalan söylemek" ('Telling a lie with tail'): Telling a big lie.

When the idioms are examined carefully, it is seen that the word tail which has a symbolic usage expresses two different concepts: In the first 18 idioms, it clearly indicates the concepts of 'honor and dignity'; 'power and will'. Essentially, we can say that the concepts of 'honor and dignity' and 'power and will' are interrelated and feed each other. In other words, especially in ancient feudal societies, a powerful man is also honorable and an honorable man is also a powerful. For this reason, we can say that the first 18 idioms reflect the same view and indicate the concept of 'honor and power'.

The meaning of 'tail' mentioned in idioms 19, 20 and 21 differs from the meaning in the first 18 idioms as it symbolizes the concept of 'continuity' and 'coming from behind'.

The concept expressed by the last idiom is not clear according to us. It may express that the lie is big or the concept of continuity.

\section{Kyrgyz Dialect}

\section{The "kuyruk" ('tail') in the idioms of}

The idioms compiled from Kyrgyz Dialect are taken from the dictionary, Krrgz Tilinin Frazyeologiyalık Sözdügü (Osmanova et. al. 2001).

1. "Kuyrugun basuu" ('Stepping on someone's tail'): To make someone angry, to attracting his curse, to make him crazy. It is used to describe the situations in which a person is subjected to material and moral attack.
2. "Kuyrugun buroo" / "kuyrugun tolgoo" ('Twisting, winding someone's tail'): To have someone obey, to warn acrimoniously.

3. "Kuyrugun karmatpoo" (Not to give the tail to someone's hands'): To stand firm. It is used describe the people who do not surrender to another's will easily.

4. "Kuyrugun kıpçuu" / "Kuyrugun kısuu" ('To pinch someone's tail'): Being silent because of fear, usually, it means to terrify a person, to threaten someone to bring him to someone's idea.

5. "Kuyrugun sirtka saluu" ("Releasing his tail on his back'): To act alone, independently, to go his own way, not to act jointly. It is used to describe the state of the person who does not obey, does not stop doing what he knows even it is wrong.

6. "Kuyrugun şiypandatuu" ('Wag the tail'): to be around someone by being tolerant. Essentially, it is used to describe a person giving up his strong, proud stance.

7. "Kuyruguna kalbir bayloo" / "kuyruguna kalbir taguu" ('To attach a can to the tail'): Gossiping after someone, humiliating someone by infamizing.

8. "Kuyruk tüyüü" ('Tying the tail', 'running away'): To get away, to disappear, not to fall into the hands of another person, running away. It means that a person who is to be taken under obedience gets away from there by not consenting to this situation and runs away.

9. "Kuyrugu üzülüü” ('Someone whose tail breaks off): To finish, to run out, to end.

10. "Kuyrugu üzülböö” ('Someone whose tail doesn't break off): Not to finish, not to run out, not to end.

11. “Kuyrugun üzüü” ('Breaking off the tail'): Completing an ongoing job.

12. "Kuyruk ulaş" ('Linking tail'): To line up one after another, to get close to each other, to be close.

13. "Kuyrugu cok" ('Tailless'): This idiom is an adjective used for people and means 'trickster, cunning person'.

It is seen that 'tail' words in Kyrgyz is shaped around two concepts as in Turkey Turkish: in the first 8 
idioms, 'tail' means 'honor, dignity, power, will'. When we consider the information given in the dictionary where the idioms are taken, the idioms 9, 10 and 11 are the idioms expressing the continuity of a work and they are the equivalents of 'continuity, extension'. There is no information in the dictionary indicating that it is used for people. However, similar examples in other dialects suggest that they can be used for people. For example, kuyrugun ürüï (breaking off the tail) may mean that the person is disabled.

In idiom12 Kuyrugu cok (Tailless), the meaning of the word tail is not clear. We cannot conclude from the information in the dictionary whether trickster person is called as 'Tailless' because he doesn't leave any trace behind or he is dishonorable or both. However, when it is considered with the idiom 'Being a tailless lion' which means 'To act as strong although really powerless' in Turkey Turkish, it can be said that the word Tailless' in the idioms is shaped around the concept of 'weakness' and the meaning 'trickster, cunning person' in Kyrgyz developed based on the concept of 'weakness' (with the idea of 'The weak man cheats').

\section{Uighur Dialect}

The "kuyruk" ('tail') in the idioms of

The idioms related to our subject in Uighur Dialect are taken from the dictionary, Uygur Tilinin İzablik Frasyeologizilike Sözlügi (Hemdulla 1984).

1. "Kuyrugini talimak" ('Biting his own tail'): To hurt himself, to be angry with himself, to feel sorry. It is used to describe situations in which a person harms himself and his personality materially and spiritually.

2. "Kuyrugini kum basmak" ("Covering his tail with sand'): Not leaving anything behind; disappearing without leaving a trace in the world. This idiom is also used for people who have lost their power and have no trace of their power.

3. "Kuyruk tutturmaslik" (Not to allow his tail to be touched'): Not to accept his mistake; it is used in the same scope with the idiom; Kuyrugun karmatpoo (Not to give the tail to someone's hands) in Kyrgyz.

4. "Kuyruk şipanşsitmak" ('Wag the tail'): Flattering to someone. The idiom is used to describe people who compromise their robust, strong, honorable stance. It is used in the same scope with idiom; Kuyruk sallamak: (Wag the tail) in Turkey Turkish and Kuyrugun siypandatuu (Wag the tail) in Kyrgyz.
5. "Kuyruk kötirivalmak" ('Lifting the tail'): Become arrogant, disliking those around him, to see himself superior to them.

6. "Kuyrukni tikivetmek" ("Making the tail upright'): To run away for fear. It is used in the same scope with the idiom; Kuyrugun sirtka salun (Releasing his tail on his back) in Kyrgyz. It is used to describe the situation of people running away so that not to do something they do not want.

7. "Kuyrukni hada kilmak" It has the same meaning with the idiom, Kuyrukni tikivetmek ("Making the tail upright'). ('Lifting the tail'): Become arrogant, disliking those around him, to see himself superior to them.

8. "Kuyrukni dingaytivalmak" It has the same meaning with the idiom; Kuyruk kötirivalmak (Lifting the tail).

9. "Kuyrukni içine tikivalmak" ('To lower the tail'): To hide himself.

10. "Kuyruk bolup kalmak" ('Being a tail)': To tag behind someone, to be an add-on. It is used in the same scope with idiom; Kuyruk olmak (Being a tail) in Turkey Turkish.

11. "Kuyrugi üzülmeslik" ('Having an endless tail'): Continuation of a work without stopping.

12. "Kuyruk körsitip öpke satmek" ('Showing the tail but selling the liver'): It indicates fraudulence and hypocrisy.

The first nine out of the 12 idioms, just as in Kyrgyz and Turkey Turkish means 'honor, dignity; will, power, power'. The $10^{\text {th }}$ and $11^{\text {th }}$ idioms mean 'continuity, 'extension'. 'Fatty meat' in idiom 12 is used in the meaning not used in other dialects (Turkey Turkish and Kyrgyz).

\section{Conclusion}

It is clear that idioms made with the word 'tail' emerge as a result of metaphor from nature to man. The tail shapes reflecting the moods of animals were transformed into idioms expressing the moods of people, their economic, social and psychological situations in society and their behavior through metaphors. The symbolic meaning of the concept of 'tail' in Turkey Turkish, Kyrgyz and Uighur, may describe the meaning of long upright tail in mountain goat tamghas used as ideograms at the top of the Old 
Turkic inscriptions (in Mongolia, Tuva). According to this;

Upright tail: It means honor, dignity, power. The higher and more upright tail refers to higher degree of the person (or tribe, family, etc.) to which the petroglyph represents and higher level of title in the context of these concepts (honor, dignity, power, might).

Putting the tail between the legs: It is an expression of dishonor, dishonesty, deprivation of power and capacity, and consequently escaping and being away from the society.

Waging the tail right and left: It is an expression of dishonor, dishonesty, deprivation of power and capacity, and consequently flattering.

Being Tailless: General opinion as a result of idiom sample from Turkey Turkish and Kyrgyz and in the light of this study is that the concept of 'Tailless' means 'weakness'.

The tail theme in the mountain goat petroglyphs is understood to represents the person drawing the petroglyphs (or the person whom the petroglyph represents) and his position in society. The exaggerated upright and long tail in ancient khan inscriptions indicates that the khan is more powerful than anyone in society in terms of honor, power and capacity, and cannot be compared with anyone on this matter. That the exaggerated long upright tails seen in the khan inscriptions of Old Turkic times are not seen in the mountain goat figures on the rock arts of the Old Turkic times (see Grach's table above) indicates that people drawing the petroglyphs couldn't draw the figures as they wish and suggests that there may be some rules limiting them.

In previous studies, it was revealed that the tamghas with mountain goat figure seen in the khan inscriptions of Old Turkic times mean 'the symbol of sovereignty and khanate'. In this study carried out with the method which we call "The Method of Petroglyph Analysis based on Idioms", it is revealed that exaggerated long upright tail understood to have been especially emphasized in the tamghas with mountain goat figure and therefore used as an ideogram means 'honor and power'. When evaluated as a whole; It is concluded that the mountain goat tamghas in the khan inscriptions express 'the symbolic meaning of khan who is more honorable and stronger than anyone'.

It is of course an exaggeration to assert that all the details in rock paintings can be explained by using
'The Method of Petroglyph Analysis based on Idioms'. However, as indicated in the example of 'tail', many concepts (the animals such as ram, snake, pig, bull, etc. and their body details such as horns, genital organs, etc.) can be explained with this method and the understanding on the role of petroglyphs and the belongings of petroglyphs in the social communication processes.

\section{References}

Alok, E., 1998. Anadolu'da Kayaüstü Resimler. İstanbul: Akbank Yayınları.

Aly1lmaz, C., 2016. Gobu"stan'in Gizemi (Kipcaklar"a Giden Yol). Ankara: Bitlis Eren Üniversitesi Yayınları.

Aly1lmaz, c., 2005. Orbun Yą̧tlarının Bugünkü Durumu. Ankara.

Demir, N., 2010. Kaya Üstü Resim (Rock Art) Olarak Dağ Keçisi/Elik ve Tarihî Altyapısı. ZfWT (Zeitschrift für die Welt der Türken), 2(2), 5-23.

Caferzade İ., 1999. Kubistan, Kayaüstü Resimler. Baku. 715.

Esin E., 2006. Türklerde Maddi Kültürün Oluşumu. Kabalc1 Yayınevi, İstanbul.

Francfort, H. P., 2001. The Study of the Petroglypsh of Central Asia: The State of the Rock Art. Petroglyps of Central Asia, Ed. Kadicha Tashbayeva, Bishkek, 5-7.

Grach, A. D., Грач, А. А.] 1973. Вопросы датировки и семантики Аревнетюркских тамгаобразных изображений горного козма. Тюркологический сборник 1972, Москва: Наука, 316-333.

Hemdulla, R., 1984. Uygur Tilinin İablik Frazeologiyilik Sözlügi. Şincạ: Halk Neşriyati.

Khujanazarov, M., 2001. Petroglyps of Uzbekistan', Petroglyps of Central Asia. Ed. Kadicha Tashbayeva, Bishkek, 80-121.

Kubaryev, V. D., ve Matochkin, E. Р., [Кубарев B. А., Маточкин Е. П] 1992. Петроглифы Алтая, Новосибирск: РАН.

Marikovskiy, Р. І.,, [Мариковский П. И.] 1999. Камни рассказывают. Алматы: Средо. 
Martinov, A., 2013. Altay Kaya Resimleri. Atatürk Kültür Merkezi, Ankara.

Mert, O., 2007. Dili Vadisi'nde Petroglif ve Damgalar. Atatürk Üniversitesi Türkiyat Araștırmalar Dergisi, 34: 233-254.

Novgorodova, Е. А., [Новгородова Э. А.] 1984. Мир петроглифов Монголий. Москва: Наука.

Okladnikov, А. Р., [Окладников А. П.] 1981. Петроглифы Монголий. АенинграА: Наука.

Osmanova, C., Konkobayev, K., Caparov, Sh., [Османова Ж., Конкобаев К., Жапаров Ш.] 2001. Кыргыз тилинин фразеологиялык сөзАүгү. Бишкек: КТМУ.

Parlatır, İ., 2008. Atasözleri ve Deyimler II -Deyimler. Haz. İsmail Parlatır, Ankara.

Radlov, V. V., [Рациов В. В.] 1892. Атлась Аревностей Монголіи типографія императорской академіи наукь. СанктПетербург: edition 1995 Ankara Baskısı. TIKKA.

Somuncuoğlu, S., 2012. Damgaların GöçüKurgan/Ankara Güdül Kaya Resimleri (The Migration of Tamga/Stamps-Kurgan Ankara Güdül Rock Engravings). İstanbul.

Samashyev, Z., 2001. Petroglyphs of Kazakhstan. Petroglyps of Central Asia, Ed. Kadicha Tashbayeva, Bishkek, 151-220.

Şahin, İ., 2012. İçel/Gülnar'da Eski Türklere Ait Yeni Tespit Edilmiş Epigrafik Belgeler: Tanıtımı ve Ön Değerlendirmesi. Türklük Bilimi Arastırmalar (TÜB AR), 31: 275-300.

Tashbayeva, K., 2001. Petroflyps of Kyrgyzstan. Petroglyps of Central Asia Ed. K. Tashbayeva, Bishkek, 9-79.

Yurtbaş1, M., 1996. Örnekleriyle Deyimler Sözlügü. Özdemir Yayınc1lı, İstanbul. 